\title{
DECLASSIFIED
}

$\mathrm{HW}-\mathbf{3 2 3 7 2}$

nequing

DE93 003399

$\odot$

-

Distribution

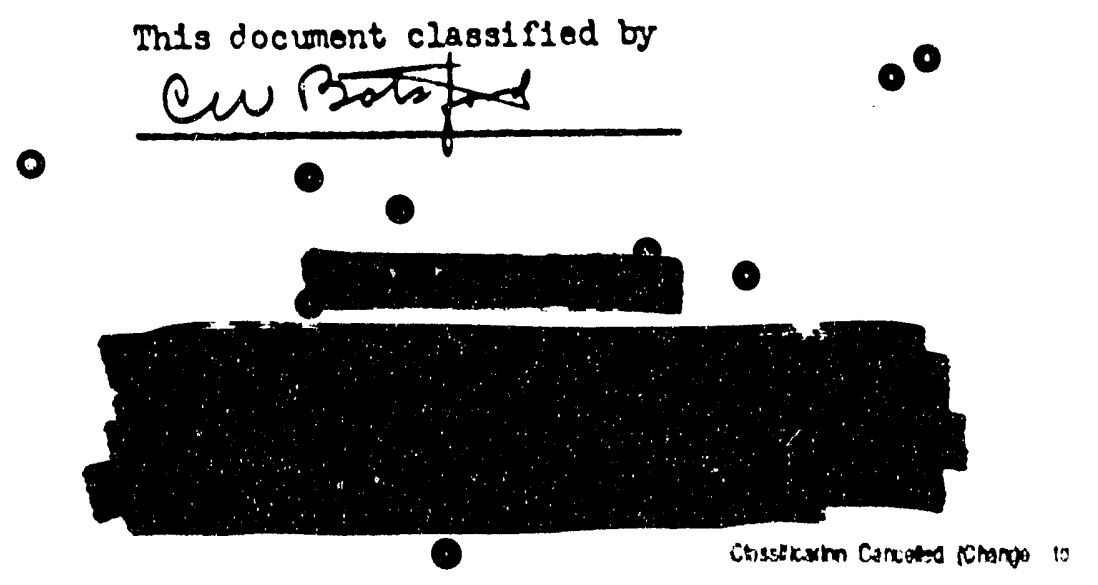

\#1. CW Botsford

\#2 RR. Bloomstrand

\#3 CS Bucholz

\#4 TW Hauff

\#5 RT Jasko

\#6 AR Magutro

\#7 RO Meharn

$\# 8$ FJ Mollerus

\#9 VD Nixon - CR Bergdahl

$\$ 10$ OH Pilkey

\#11 OC Schrooder

H12 HE Ostruck

\#13 700 Files

\#I 300 Files

\#15 Yellow Fi:e

-

-

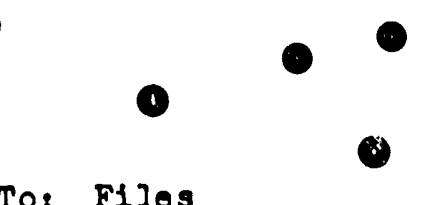

\section{PROCESS TEST MR-105-23}

- CATHODIC PROTFCTION OF THE 107-C RETENTION BASTNS

OBJECT

$\bullet$

The object of this test is to determine the feasiolif of proventing corrosion of the loje retention basins by the installation of a smell scale cathodic protegtion system.

BASIS AND, JUSTIFICATION

10

The 107-C retention basins are fabricated fram wolded carbon steel sheets and aro appraximately 330 feot in diametor and about 16 feet in holght with an open top. Reactor offluent water at temporatures of $50-60 \mathrm{C}$ is stored in them prior to dischargo Into the Columbia RIver.

Corrosion of the Ingide surfaces of the tanks has been ovidenced by bllstering and loosenting of the palnt coating. If an impervious coating such as paint. fal 18 to provido adequatoprotoction against corrosion, cathodic protection is usually consldered to be the best altomative mothod of corrosion prevention. 0 Thefefore, the installation of a smali scale cathodic protection system designed to 1avestigato and establigh crftoryarfor a full scalo 1nstallation appears warranted.

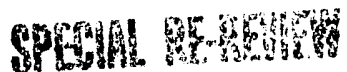

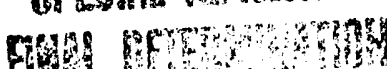

rows

-

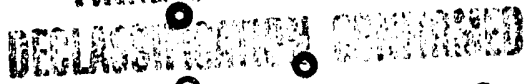

BHP Aevain $96-17-81$ $\int\left[\begin{array}{lll}2 & 6\end{array}\right.$

This document consists of

July 12, 1954 COPY 1 of 1 . 


\section{DECLASSIFIED}

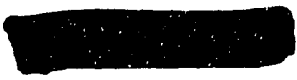

To: FIIes
- -2-

-
32372 IN- 92797

$7-12.54$

\section{BROCEDURE}

The test installation wlll be made on the west 107-C retention basin. The equdpment essentially cons: sts of two graphlte and two aluminum anodes which wlll be suspended fram bracisets mounted on the tank wall. The anodes wlll be placed along the edgo of the tank appraxdmately seven to elpht feet from its imer surface :and fram 15 to 20 feet apart. A DC potential no greater than 24 rolts will be impressed on the system. Exact positioning of the anodes will be detomined fram potential moasurements at the anodes and tank walls made with a hl gh resistance voltmetor.

Underwater photography will be used for determining the extent of the protection supplied by the tost installation.

\section{SCHEDOLS}

- Mstallation of the cathodic protection system wlll begin as soon as This tese is authorized and all equipment arrives on-sitis. The duration of the test will not exceed 18 manths from the date of installation.

.

\section{$\cos 5$}

t or Installation costs w1ll be Incurred by the Reactor foction, as all work will be dane wider Deslgn Section approprlations for this studye Necessary work orders, work requests, etc.o w1ll be provided by C. B Bucbolz, Englnoering Standards and Materlals onit, Design Section.

The Process subsection assumes the responsibillty for coordinating cooperative offort between Design Section and Reactor Section personnel, and for preparing

a flnal report.

$\odot$

$\odot$

- R. R. Bloomstrand

Reactor Oper stion Enginosing

Process Sub-Sortion

REACTOR SECTIU.

-

○

-

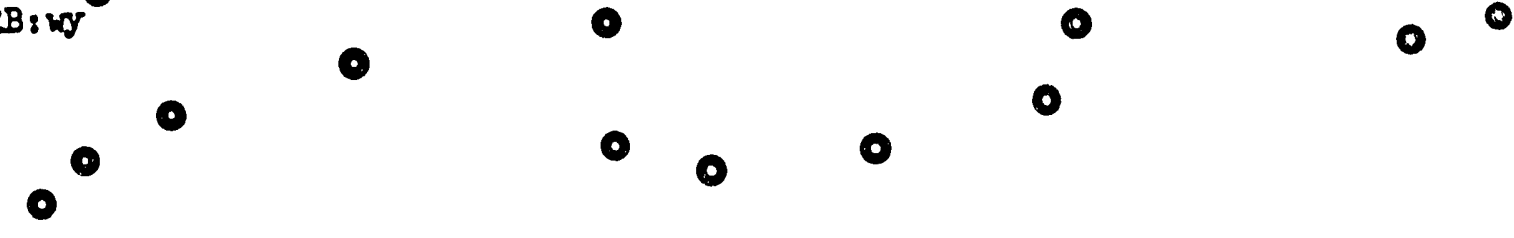


DECLASSIFIED

To: Files

$-3-$

0

$H W-32372$

$7-12-54$

0

0

o

APPROVALS

0
0

0

Rodereun

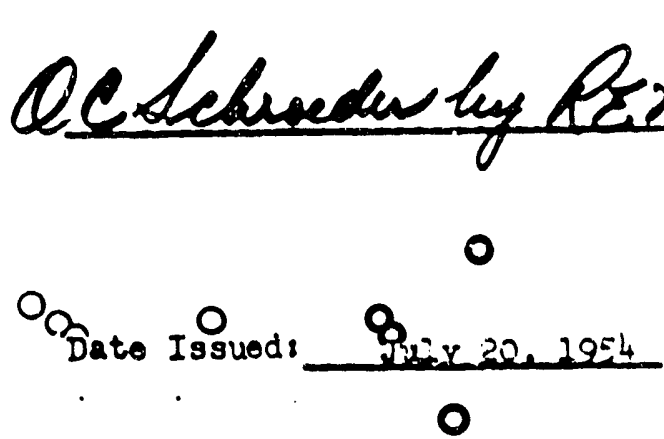

$$
\begin{array}{lllllll}
1 & 0 & & & & & \\
0 & & 0 & 0 & 0 & 0 & 0
\end{array}
$$

0

0

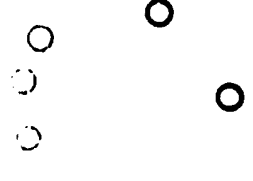

$$
\begin{aligned}
& 0 \\
& 0
\end{aligned}
$$

0

Q
0

$$
0_{0}^{00} 0
$$

$\begin{array}{llllll} & 0 & 0 & 0 & 0 & 0\end{array}$

0
0

○

o

0 c

8

$$
0
$$

00

o

0

o

0

0

DECLASSIFIED 
DATE

FILMED

215193 
